\title{
"Al salvaje todo le llama la atención" Loreto de Pedro Dávalos y Lissón (1894)
}

Manuel Cornejo Chaparro

\section{Resumen}

Pedro Dávalos y Lissón relata una serie de crónicas que lleva el título de Loreto, publicada en el diario El Comercio en 6 entregas en los meses de enero, marzo, abril, junio y julio de 1894. En ellas refleja, a través de la imagen del viaje, el propósito de someter la intricada y fabulada región amazónica al proyecto civilizatorio, pero también justifica el papel del letrado que transita -armoniosa o conflictivamente- este puente discursivo entre las letras y el novedoso mundo de la industria gomera y consolida su aporte en la construcción de ese frustrado intento decimonónico de nación imaginada.

\section{Summary}

Pedro Dávalos y Lisson reports in a series of Chronicles that carries the title of "Loreto", published in the newspaper "El Comercio" in 6 installments in the months of January, March, April, June and July 1894. In them they reflect, through an image of the journey, the purpose of submitting the intricate and fabled Amazon region to the civilizing project, but also justifies the role of a learned person who transits - harmoniously or conflictingly - this discursive bridge between letters and the new world of rubber industry and consolidates its contribution in the construction of this nineteenth-century frustrated attempt of an imagined nation.

Palabras claves: Loreto-proyecto civilizatorio-representación del indígena-Amazonía 


\section{Palabras viajeras}

En 1894, los lectores de Lima, comienzan a recorrer imaginariamente la selva a partir de la serie de crónicas Loreto de Pedro Dávalos y Lissón ${ }^{1}$. El trayecto de este cronista, transcurre entre Tarapoto, Moyobamba e Iquitos, lugares casi inaccesibles a los limeños de fines del siglo XIX ${ }^{2}$.

La construcción y "aperturas" de la vía del Pichis despertaron el interés en la naciente opinión pública urbana, durante la década de 1890. Numerosas notas, descripciones de cronistas, misioneros, militares y viajeros, algunas ilustradas, dejan evidencia de la importancia que la Amazonía y su integración vial por la región central significó ${ }^{3}$.

¿Pero cómo se va forjando esta nueva mirada hacia la Amazonía, ataviada, eso sí de los mismos extravíos coloniales? ¿Cómo se construyen estos relatos y discursos hegemónicos -como el de Dávalos y Lissón- que luego consolidan imaginarios que desde la ciudad letrada legitiman la conquista de la Amazonía bajo discursos modernizadores como espacio de "regeneración nacional" o de "porvenir de la patria"? Hay que señalar que esta imperiosa conquista de la selva, se presentó luego de la devastadora guerra con Chile no solo como de vital importancia para nuestra reconstrucción económica sino para la conformación de un renovado nacionalismo peruano (García Jordán 2001:170)

* Agradezco a María Eugenia Yllia y Juan Carlos La Serna por sus acertados comentarios que contribuyeron a la mejora de este artículo.

1 Pedro Dávalos y Lissón (Lima 1861-1942) historiador y novelista. Salvo algunas reseñas sobre su obra en la prensa de la época y algunos comentarios de Raúl Porras Barrenechea y Luis Alberto Sánchez, su obra ha sido relegada. En 1904 publicó La Ciudad de los Reyes. Época histórica de 1884 a 1895. También ejerció actividades mineras y empresariales. Formado bajo los ideales de su tío Carlos Lissón, como hombre de letras, Dávalos y Lissón produce textos históricos desde su cercanía a los círculos de poder, especialmente a José Pardo y Augusto B. Leguía (Pollarolo, 2015) En 1895, La Sociedad Geográfica de Lima (de la cuál Dávalos y Lissón fue socio corresponsal) editó bajo el título de Región Fluvial de Loreto, sus dos primeras crónicas escritas en Moyobamba el 30 de setiembre y 9 de octubre de 1893, y enviadas al Diario El Comercio de Lima. Estas entregas no se llegaron a publicar en este diario pero para un mayor acercamiento al discurso de Dávalos y Lissón resulta relevante señalar algunos puntos como: los motivos de su viaje: "negocios particulares me traen por este Departamento, al que tendré que visitar en toda su extensión", además de su deber de escribir: "con espíritu recto y la imparcialidad que me da un trabajo independiente, hacer una descripción de esta montaña del Perú, habré hecho a los estadistas de nuestro país, y a esa juventud que está ansiosa de trabajo, un positivo servicio" pero también nos llama la atención que califica la conferencia de Samuel Palacios como "una fantasía". El coronel Samuel Palacios Mendiburu encabezó la Comisión Especial creada en 1887 por el Gobierno para la exploración de Loreto. Palacios tiene puntos de vista diferentes a Dávalos y Lissón, entre ellos la factibilidad de la vía del Pichis, la colonización de Loreto y "el régimen civil en que deben vivir los aborígenes".

3 Estas notas aparecieron en diversos medios como El Comercio, El Perú Ilustrado, Lima Ilustrado, Monitor Popular, entre otros. 
En Dávalos y Lissón, podemos apreciar dos aspectos a resaltar que nos ayudan a entender esta crónica, no solo la puesta en escena escribal, sino su reclamada autoridad en esta reimaginación finisecular de la nación. El primer aspecto es que a pesar de la reciente inauguración de la vía al Pichis (solo tres años antes), vía oficial que acortaba el viaje a Loreto, Dávalos y Lissón utiliza la antigua vía colonial -usada por los conquistadores en sus infructuosas y febriles búsquedas de El Dorado y otras quimeras coloniales- que iba por Pacasmayo, Cajamarca, Chachapoyas, Moyobamba y llegaba hasta Yurimaguas; de ahí se continuaba por río hasta Iquitos. Este viaje podría durar tres meses ${ }^{4}$. Lo segundo es lo escueto y a la vez abarcador del título de la serie de notas Loreto. A pesar que el cronista no recorre en su totalidad esta enorme región y solo recoge el punto de vista del colono cauchero, esboza una serie de descripciones, alegorías, antítesis, paisajes, metáforas, que luego posibilitan que la narrativa se convierta en una legitimación natural de la autoridad del viajero, ésta se ve esgrimida tanto por el aspecto de letrado como de un avizorador hombre de empresas futuras. La escritura producida desde la misma región amazónica por Dávalos y Lissón y enviada por entregas a El Comercio en 1894 legitima al cronista y es asumida como verosímil por los lectores limeños de la época. Loreto resulta no solo crónica de viaje sino la apuesta desde la escritura de una manera de conquistar esta región ${ }^{5}$.

Hay que destacar que uno de los hitos fundacionales en la representación del Oriente peruano es la construcción de la vía del Pichis (selva central) que posibilitaba una ruta más cercana a Loreto. Esta vía bajo la dirección de Joaquín Capelo fue concluida y entregada el 15 de noviembre de $1891^{6}$. La construcción de esta vía también posibilitó la reelaboración de discursos e imágenes -con evidentes rezagos coloniales-sobre el territorio amazónico, región casi desconocida por la sociedad limeña de la época.

$4 \quad \mathrm{Al}$ utilizar esta vía colonial, el cronista nos sugiere una lectura tradicionalista del territorio. "Por entonces, los exploradores extranjeros aconsejaban utilizar el ferrocarril a La Oroya y Cerro de Pasco, para allí franquear la cordillera de Huachón, los cerros de Yanachaga y el río Palcazú. Decían que por ahí se ahorraban 80 leguas de Lima a Iquitos" (Espinoza 2016:234) Dávalos y Lissón asegura que este viaje puede durar 25 días (1905: 105).

5 Como afirma Juan Carlos La Serna: “Las regiones amazónicas representadas en la «temprana fotografía oficial» corresponden a los objetivos expresados por las propias lógicas e intereses del Estado peruano a través de sus diversas instituciones y se pueden clasificar, temporalmente, en la medida que los ritmos de la colonización va atravesando nuevos territorios. Así, las primeras imágenes reflejan las entradas de exploración al piedemonte, en Chanchamayo y las montañas del Cusco, o las exploraciones fluviales a los ríos navegables del Amazonas (Ucayali, Tambo y Pachitea). Más adelante el repertorio se amplía, en la medida que el proceso de dominio territorial se expande espacialmente" (2012) Este concepto atribuido a las imágenes visuales se puede extender también a la producción escrita. Loreto es un ejemplo de ello. El avance colonizador, la empresa gomera y el papel del Estado requieren un discurso que legitime, propicie e incorpore esta "conquista" al imaginario social de la capital peruana.

6 Ver Larrabure y Correa (2006: tomo III 278-304) La vía del Pichis fue varias veces inaugurada. 
¿Pero por qué encontramos esta escritura fronteriza en Dávalos y Lissón? Planteamos como hipótesis esclarecedora la conversación del joven Pedro Dávalos y Lissón con el civilista Isaac Alzamora en 1883. Esta entrevista constituye "uno de los testimonios más representativos de las transformaciones intelectuales que ocurrieron en la élite política limeña luego de la Guerra del Pacífico" (Mc Evoy 2017:29). En palabras de Alzamora, ya no eran abogados, los maestros, los literatos, los burócratas o los militares los que iban a colaborar en las transformaciones que el país requería con urgencia, sino aquellos que se movieran en el mundo de la alta industria, el gran comercio y la banca (Dávalos y Lissón 1941: 11, citado en Mc Evoy 2017:230). Entonces, en Loreto, podemos apreciar la construcción de un narrador que transita este puente discursivo entre las letras y el novedoso mundo de la industria. El contexto finisecular y de inicios del xx marca el posicionamiento de una generación de "gestores" políticos de raigambre liberal y positivista, desde Larrabure y Correa, Óscar Salomón, Cisneros, Pedro Paulet, entre otros. Que desde diversos puestos de gobierno, especialmente el Ministerio de Fomento insisten en el valor del emprendurismo individual y el valor estratégico de la Amazonía como fuente de recursos ${ }^{7}$.

Podemos señalar que la crónica de Dávalos y Lissón no representa solamente la frontera amazónica ni a los sujetos indígenas sino también esgrime "los mundos posibles" de procesos modernizadores de esta región: Esto resulta clave en el discurso de Dávalos y Lissón ${ }^{8}$. A fines del siglo XIX, época en que se publica esta crónica, este escritor forma parte de los intelectuales que proponen y exponen "un discurso legitimizador capaz de convencer a las mayorías de las bondades de determinado proyecto hegemonizador"9 (Mc Evoy, 2017: 51).

Loreto se publica en El Comercio en 6 entregas en los meses de enero, marzo, abril, junio y julio de $1894^{10}$. Dávalos y Lissón refleja a través de la imagen del viaje el proyecto de someter la intricada y fabulada región amazónica al proyecto nacional ${ }^{11}$. Tal como señala Ramos para la crónica de fines del siglo XIX en las ciudades

$7 \quad$ Juan Carlos La Serna (2019) comunicación personal.

8 Para una aproximación a la biografía y trayectoria de Pedro Dávalos y Lissón ver el excelente trabajo de Giovana Pollarolo, 2015. Para aproximarse a su novela "La Ciudad de los Reyes" Ver: García Bedoya (2012: 221-232) publicada en 1906, Dávalos y Lissón representa a personajes loretanos como protagonistas de esta obra.

9 En esta representación del sujeto indígena y del territorio amazónico resulta relevante, además de los propios textos, la circulación y uso de fotografías que permitían esta "reproducción de imágenes estereotipadas y exotizadas del territorio amazónico en la opinión pública nacional" (La Serna 2013) El 11 de enero se publica en El Comercio una crónica del 15 de noviembre de 1893, escrita en Yurimaguas; el 28 de marzo se publica una crónica del 31 de diciembre de 1893, escrita en Iquitos; el 23 de abril se publica una crónica del 20 de febrero, escrita en Nazareth; el 7 de junio se publican dos crónicas escritas el 10 y 16 de abril; el 5 de julio se publica la última crónica una crónica escrita el 2 de mayo de 1894.

11 La Amazonía constituye una construcción discursiva que transita la colonia y la república, esta construcción refleja esta perspectiva ahistórica en que se ha pretendido asumir esta región. Como afirma Ana Pizarro, solo hemos recibido una información parcial: la del conquistador. La 
latinoamericana (1989: 126) en Loreto constatamos la existencia de una retórica del viaje que se representa en un sujeto que al transitar por la selva señala una ruta -un discurso- en el trayecto del viaje. El viaje ordena la fragmentación y caos de la periferia, estableciendo e inventando tradiciones, conjunciones, puentes entre espacios desarticulados como Lima y la Amazonía ${ }^{12}$. Pero además, apreciamos una respuesta del letrado frente al proyecto modernizador del Estado-Nación.

\section{“AAsí cómo puede progresar la población de estos lugares?”}

En Dávalos y Lissón, resultan evidentes los rasgos europeizantes en la construcción del otro. Siguiendo a Said (1990) podemos apreciar en Dávalos y Lissón que el discurso del otro (amazónico), se construye como dispositivo de la constitución "propia" del cronista que elabora ese discurso. El "otro" amazónico es un elemento hereditario del imaginario colonial. Es así que el proyecto civilizatorio presenta a la selva como un espacio donde predomina la ausencia estatal y el control sanitario refiriéndose a la presencia de una epidemia de viruela que golpea a la población del pueblo:

"Al fin he podido abandonar Tarapoto y al salir de él desaparece de mi espíritu la desagradable sensación que nos causa, el oír, hora á hora, a la campana parroquial... el continuo toque fúnebre que anuncia el acarreo de muertos, siendo lo peor de este flagelo, que la mortandad diaria sigue siendo numerosa...y esto que hoy pasa en Tarapoto, ha durado un año en Moyobamba, y sus pueblos vecinos" (El Comercio, 11 enero 1894).

Tarapoto, una ciudad de montaña simboliza un espacio de muerte pero también la ineficiencia de la acción estatal. Esta imagen -no recogida por otros viajeros de la época- le permite al escritor viajero, en un lugar lejano a la metrópoli, precisar su autoridad y su espacio en la sociedad. Constituye además la entrada a la selva... La voz letrada asumida en el párrafo anterior, relatada en pretérito y asumida como feroz recuerdo es acompasada por la voz del agente empresarial.

Por eso afirma que:

"Así como puede progresar la población de estos lugares? Dispensan á Loreto del pago de contribuciones para que adelante $y$ sus autoridades, representantes $y$ municipalidades, ni se dan cuenta de que la disentería y la viruela lleva el quince por ciento de pobladores en cada gira que hace por estas regiones" (El Comercio, 11 enero de 1894).

Amazonía como espacio físico y humano, cultural, contaba con elementos que representaban dispositivos simbólicos. El resultado de ello fue la elaboración de textos con elementos en común, cuyas relaciones representan los imaginarios de la sociedad occidental (Pizarro, 2007: 28-29) 
Se denota el intento del cronista en expresar los límites de una autoridad, un lugar de enunciación que permite al letrado, como ya lo hemos afirmado anteriormente, la legitimación de su discurso. Como se conoce, la escritura proveía un modelo para la estructuración de la nación. En este caso, el texto narrativo opera como un discurso necesario para proponer soluciones a temas que rebasan los límites convencionales del campo literario institucional (Ramos, 1989).

También se denota esta autoridad letrada cuando describe su paso por Chazuta y señala:

"Pobre ranchería hoy completamente abandonada por sus semi salvajes pobladores, los que se han internado en los bosques, después de que asesinaron al Subprefecto Bello y sus cuatro soldados. En los bosques viven muy tranquilamente, sin que, ni siquiera, se intente el tomarlos. Pobre principio de autoridad" (El Comercio, 11 enero de 1894) $)^{13}$.

Pero lo que sorprende en Dávalos y Lissón es la ausencia del carácter agresivo de la naturaleza amazónica retratado por otros viajeros de la época. En la serie de crónicas de Dávalos y Lissón, el bosque es visto como un espacio bucólico ${ }^{14}$, además el río, ser mítico que fluye, configura el límite del mundo social:

"Que sensación tan extraña, tan nueva, tan indescriptible, la que se experimenta cuando se viaja por primera vez en los ríos de nuestro oriente; especialmente cuando se viaja de noche, y cuando la luna alumbra, magníficamente, las tranquilas aguas donde comienza lo desconocido. El silencio de esa soledad solo es interrumpido por el arrullo de las aves del monte o por el encantador canto de algún pájaro silvestre. Un caudal de ideas nuevas, de pensamientos confusos; de recuerdos vagos, de fantásticos presentimientos, vienen, entonces a nuestra mente, se agolpan en ella y nos causan una indefinible sensación, un algo inexplicable; solo puedo decir que nunca olvidaré la impresión que en mi espíritu causó la nocturna navegación en el Huallaga" (El Comercio, 11 enero de 1894).

Dávalos y Lissón estetiza el paisaje amazónico, lo representa como una escena, casi una pintura romántica. El viaje por el río a la luz de la luna se sitúa en un espacio prístino y atemporal en el marco de los valores y sensibilidad del público limeño a quien va dirigida la crónica, evidentemente con reminiscencias y miradas europeas. El viajero, protagonista del relato, construye una escena bucólica y acerca -mediante esta estrategia literaria- el escenario amazónico al lector limeño. Por una noche, no existen temores ante el acechante bosque ni incómodas presencias de insectos ni la molestia del inédito y agreste clima. En esta descripción del cronista podemos apreciar que "descripción y artificio se revelan como inseparables" de

Sobre la rebelión de los chazutinos y la muerte del Subprefecto José Bello, ver Barclay (2001) Como señala Rodríguez, "lo 'nuevo' no solo permite sino, incluso, alienta el placer estético de la contemplación del paisaje” (2000:99) 
esta manera, el relato "crea un paisaje social y moral" (Serje 2007: 66-67). En esta alteración de representaciones, el bosque emerge no solo como espacio bucólico y emblema poético sino como una inesperada antítesis de la acelerada urbanización de la capital limeña y su cada vez extraña modernidad que conlleva estilos de vida que no permiten esa mirada subjetiva hacia el yo interior.

¿Pero por qué los sujetos locales no aparecen en este segmento? Como veremos más adelante, los sujetos mestizos e indígenas solo aparecen en el relato del cronista viajero cuando se establece una relación instrumental con él, cuando informan, aportan datos, conocimientos -la mayoría de ellos anónimos- representan aquello que el cronista desea mirar, recrear y escribir (Pratt 2010). De esta manera, el cronista viajero se convierte en el verdadero protagonista. Como afirma esta autora, la mirada progresista presenta estos espacios "como paisajes vacíos, dotados de sentido solo en función de un futuro capitalista" (2010:125).

Pero también se puede observar este extravío entre la mirada empírica y la herencia cultural que en lo estético viene a rendir un paisaje agradable (Rodríguez 2000: 100) ${ }^{15}$. En Dávalos y Lissón podemos apreciar claramente esta tensión. En el pasaje anterior apreciamos no solo la mirada bucólica de la selva sino la reificación del cronista como personaje encima de los avatares de la naturaleza agreste: nada parece afectarle ni las amenazas externas, ni la subjetividad sujeta a nuevos y desafiantes escenarios. El cronista se convierte en un héroe de mímesis alta.

\section{"El desembarco en Iquitos es una desilusión"}

Pero este deslumbramiento ante lo natural tiene su antítesis en su decepción al acercarse y recorrer el espacio social, cultural de Iquitos. El proyecto civilizatorio se encuentra todavía inconcluso, la ciudad todavía no está concluida. El desencanto del cronista viajero se refleja en este párrafo:

"El desembarco en Iquitos es una desilusión. La bella ciudad vista desde el río es una población que marcha á pasos agigantados á su formación; pero que todavía no está concluida...si de lo que se llama el puerto se pasa á la ciudad, el desencanto todavía es mayor" (El Comercio, 28 de marzo de 1894).

15 La tensión entre estos dos modos narrativos consiste en el contrapunto de lo que Northop Frye denomina el héroe de mímesis alta y el héroe de mímesis baja "que producen la sensación de la naturaleza amazónica como algo cautivante pero también amenazante, que transmite el efecto de suspenso que es la idea misma de la frontera" (citado en Rodríguez 2000: 100). 


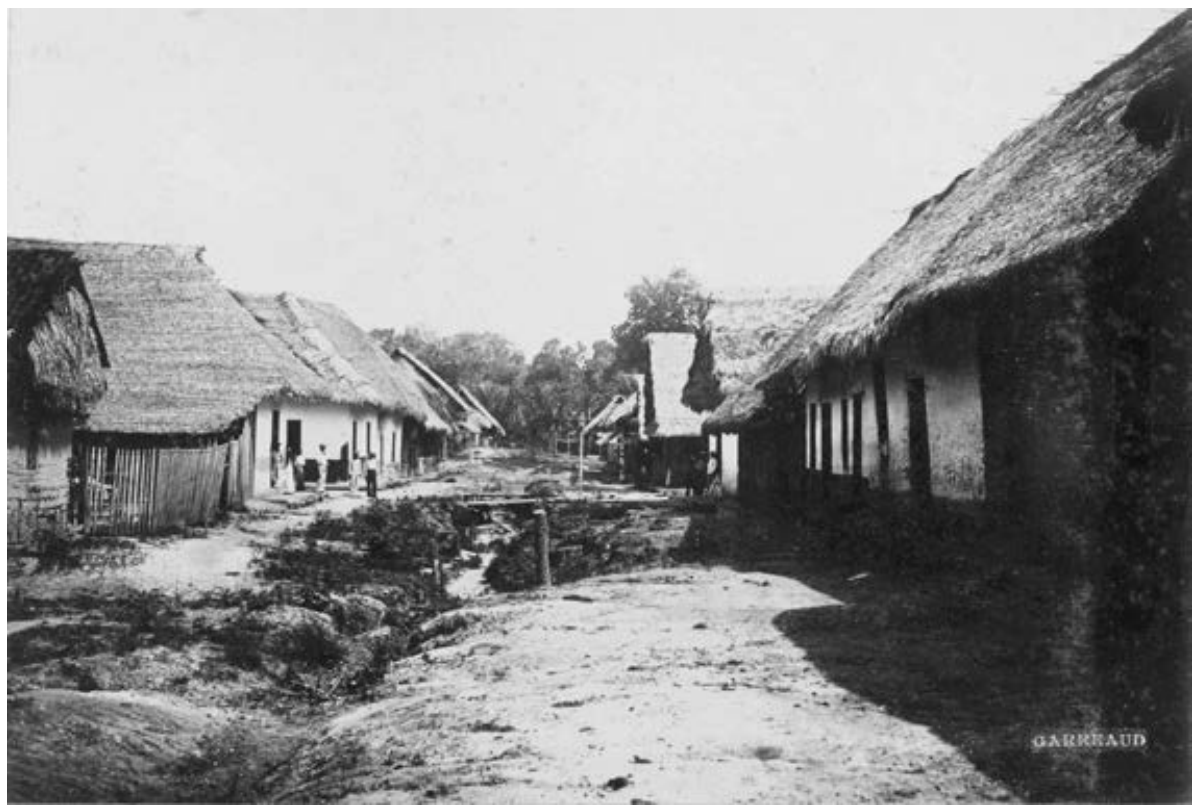

Calle Belén

Kroehle \& Huebner, 1888

Fuente: Perú 1900. Álbum fotográfico. Lima, inédito (Colección de la Biblioteca Nacional del Perú e Instituto Raul Porras Barrenechea, UNMSM)

El autor utiliza una metáfora conceptual una población que marcha á pasos agigantados que da lugar a otras enunciaciones sugeridas. Dávalos y Lissón relata, organiza, define el espacio amazónico y a sus pobladores. Para efectuar este procedimiento narrativo, el cronista, como exponente de la herencia colonial se vale de "categorías visuales" (Foucault citado en Serje, 2011: 65), aunque no está explícito, se remite a la idea de cartografía cultural. Cuando más lejos se está de Lima, más lejos se está del proyecto civilizatorio del Estado-Nación. Es interesante cómo Dávalos y Lissón acentúa su desencanto solamente en el puerto, cuando tuvo que haber sido mayor su énfasis por la transformación de toda la ciudad que evidenciaba las contradicciones de la modernidad. Por imágenes de la época, como las fotografías de Kroehle \& Huebner o de Rodríguez Lira podemos apreciar que en Iquitos convivían todavía diversos tiempos y tradiciones de aldea conjugadas con el apuro modernista. Esta confusión social se expresaba en el espacio urbano: casonas relucientes con azulejos portugueses, pero también casas de techo de palmera, calles sin pavimentar, acequias malolientes, y la misma Plaza de Armas casi una alegoría de la lucha del bosque por no sucumbir ante la naciente urbe ${ }^{16}$. 


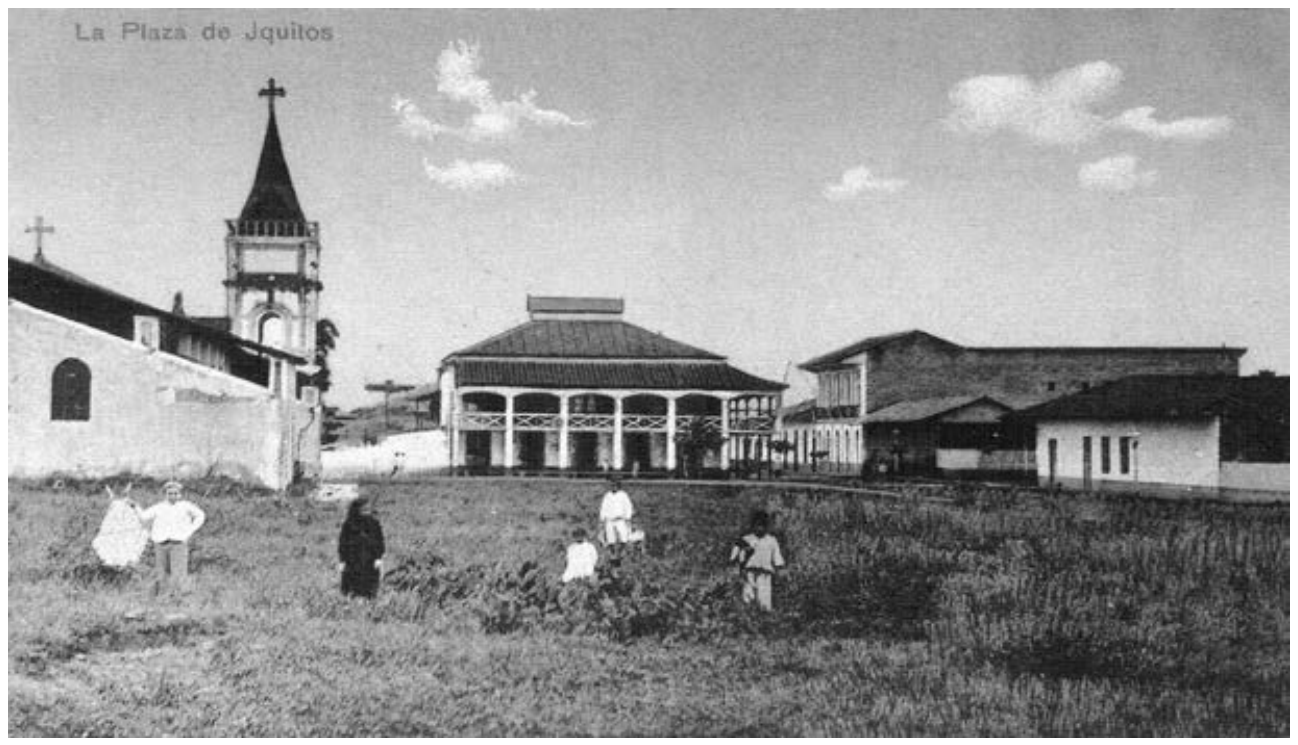

Postal coloreada de La plaza de Iquítos Manuel Rodriguez Lira ca.1900

Colección Jean-Pierre Chaumeil

Como señala Ramos, "la ciudad es transformada por el discurso estetizador" (1989: 129). En ese sentido la descripción sobre Iquitos genera discursos y establece jerarquías, subordinaciones, símiles:

"Felizmente ya principia á construirse con más gusto y elegancia. En estas nuevas construcciones, las paredes que forman la fachada á la calle, son de azulejos, iguales á los de algunos templos y conventos de Lima. Los techos se hacen de buena teja, y las puertas y ventanas están fabricadas al estilo europeo" (El Comercio, 28 de marzo de 1894).

Por eso, este símil entre la arquitectura loretana y la limeña -por demás forzada e inexacta- genera una cercanía, una herencia cultural proveniente de la metrópoli, una estética nacional. Lo amazónico -exótico y ajeno- contiene ciertas características de la arquitectura limeña tradicional ${ }^{17}$. Es decir, lo nuevo -el proyecto civilizatorio en la Amazonía- conlleva un ropaje virreinal proveniente de la capital ${ }^{18}$. En esa misma

17 En la crónica publicada en el Boletín de la Sociedad Geográfica de Lima, Dávalos y Lissón también ve semejanzas, no solo en la arquitectura, sino también en "grande analogía existe entre el loretano y el costeño. Su frente levantada, sus formas esbeltas y lo cruzado de su raza, lo distinguen a primera vista del hombre de las cordilleras" (1895: 103)

18 Como se conoce, la arquitectura loretana y el uso de azulejos portugueses estaba más vinculada a la estética urbana brasileña, específicamente de ciudades amazónicas como Manaos y Bélem do Pará. 
entrega, la descripción de un establecimiento estatal en la selva puede propiciar una alegoría no solo sobre este abandono peruano hacia el espacio amazónico sino sobre el caos y nuevamente la pugna cultura-naturaleza. Esta vez, la selva impregna y altera el proyecto modernizador:

"El patio principal, pavimentado con fondos de botella, muchos rotos ó hundidos, está tan profusamente tupido de yerba y basura, que su vista puede dar al extranjero que pise esta orilla fluvial, el dato más amplio de lo que es gobierno en el Perú" (El Comercio, 28 de marzo de 1894).

Dávalos y Lissón escribe desde esta retórica modernista cuyo núcleo (como la mayoría de intelectuales latinoamericanos del siglo XIX) es la antítesis civilizaciónbarbarie. En este viaje, el cronista emerge nuevamente como productor de imágenes de la otredad, contribuyendo a elaborar un saber sobre los modos de vida de la periferia nacional. En este caso se presenta a Iquitos como una ciudad sin tanta influencia católica que provee a la metrópoli de argumentos para iniciar una nueva etapa evangelizadora y controladora de afectos y libertades peligrosas. También se perpetúa esta idea de frontera donde los códigos y convenciones culturales se dejan de lado:

"Por lo que respecta á liberal, dudo de que exista en el mundo una ciudad en el mundo, en la que las obligaciones con la iglesia, estén tan olvidadas como aquí. En este pueblo nadie se confiesa, ni nadie fomenta el culto con una sociedad, como "Las Hijas de María", ú otras místicas ocupaciones, como sucede en grado superlativo en Cajamarca, Lima y Arequipa. El porqué de este abandono místico está, en la creencia arraigada, de que se puede vivir sin distribuciones religiosas, con tal que se ame á Dios y al prójimo" (El Comercio, 28 de marzo de 1894).

Este tipo de relato no existe en los discursos oficiales. Entonces, encontramos aquí un efecto narrativo que trata de influir en el lector limeño maneras otras de practicar la religión. La imagen de frontera también constituye una metáfora de libertad del individuo, y Dávalos consolida esta noción con esta posibilidad de no dependencia de la Iglesia. Aquí vemos un ejemplo de lo que quiere consolidar Dávalos y Lissón: un proyecto modernizador sin tanta influencia católica, más bien de una perspectiva laical. Lo interesante es que desde un discurso producido desde la periferia, el cronista trata de incidir en la metrópoli.

\section{"El salvaje gusta de ser obsequiado"}

En el párrafo siguiente aparecen los pobladores locales: "el hombre de la región fluvial" y el "salvaje"19 representados en una oposición natural. El "hombre de la región fluvial" representa al proyecto civilizatorio y, por ende, dotado de 
rasgos positivos, y el "salvaje" 20 , evidentemente posee un aura de animalidad y violencia, el cual se expresa solo a través de "la flecha traidora". El autor coloca en un mismo campo semántico a la naturaleza, al salvaje y al tigre. En esta crónica, como en otros documentos de la época, advertimos claramente, la construcción de un imaginario que colocaba al pionero, explorador o cauchero como un elemento civilizatorio y al otro lado, al indígena salvaje y ahistórico que había que civilizar (Chirif 2009) Esta figura facilita la formulación de una irreal antítesis: un afuera -el salvaje- en cuyo reverso se constituye un adentro -el hombre de la región fluvialque forma parte de un proyecto civilizatorio que conlleva "el delirio irracional por la búsqueda de riquezas" (Sloterdijik 2007).

"El hombre de la región fluvial no descanza (sic) nunca, como que nunca se apaga en él su sed de fortuna. No le arredra el hambre, las enfermedades, las fieras, los salvajes, ni las contrariedades morales...Alli mismo tenerse que internar por dos ó tres días por trochas peligrosas, en busca del codiciado caucho. Allí le espera la flecha traidora del salvaje, el ataque igualmente traidor del tigre; pero nada le arredra: lucha con la naturaleza, con el salvaje, con las fieras, con su misma gente, muchas veces" (El Comercio, 28 de marzo de 1894).

Pero además podemos apreciar cómo el cronista presenta una imagen ajena y masificada de los otros representados. Por un lado, el hombre de la región fluvial ${ }^{21}$ -extraño, por ende, al sujeto andino o al poblador costeño- que no teme a nada, capaz de dominar la naturaleza y sus propios instintos. Esta sublimación del hombre de la región fluvial resulta interesante, debido al mensaje que se quiere llegar a los lectores de la capital. La posibilidad de un proyecto civilizatorio impulsado desde los propios pioneros. Con la imagen hombre de la región fluvial, también se produce una traslación de símbolos: ya el personaje civilizatorio de nuestra alteridad interna no es solamente el hombre de montaña, el colono (aquel descrito en las crónicas de viajes e imágenes de décadas pasadas) sino también el hombre de la región fluvial, imagen del colono que se adentra más allá de la montaña: en los llanos amazónicos. Este personaje posibilita también nuevos paradigmas inconclusos: Soberanía, civilización, riqueza, naturaleza domada. Por este motivo, la región conocida como montaña -nuestra frontera decimonónica por excelencia- se renueva, se desplaza y se reconfigura en la inédita región de los ríos. Esta nueva "frontera" conlleva como hemos manifestado anteriormente- no solo nuevas "categorías visuales" sino la representación del colono, el hombre de la región fluvial -opuesto al salvaje, al que se le despoja de toda categoría positiva de humanidad, es decir: no hombres-

20 La oposición entre "hombre de la región fluvial" y "salvaje" se evidencia desde la descripción misma. El que lleva el proceso civilizatorio tiene la categoría de "hombre", el sujeto indígena amazónico no forma parte de esta categoría. Es visto como salvaje, infiel, caníbal, etc. Dependiendo estas definiciones a su adaptación o resistencia al proceso civilizatorio decimonónico.

21 Esta categorización evidencia también la predominancia del espacio natural en la configuración del perfil socio-cultural del sujeto. La región fluvial -misteriosa y lejana- está configurada en clara oposición al paisaje benévolo de la Costa (más cerca de la sociedad). 
Esta idealización del cauchero, descrita en la crónica, es desmitificada en otros relatos de la época, como los propios testimonios de caucheros recogidos por el Juez Rómulo Paredes en el Putumayo, así como la prensa limeña de la época, a partir de las denuncias de Roger Casement ${ }^{22}$. La antítesis funciona para justificar el avance colonizador y la resistencia indígena. Entonces, la flecha del salvaje que defiende su territorio se convierte en la flecha traidora, por ende, resulta una paradoja la representación del indígena a quien se le quita todo rasgo de humanidad y se le representa más cercano a la fiera -también traicionera- que al colono ${ }^{23}$.

Hay que señalar que el sujeto indígena amazónico representado como salvaje -idealizado y otrificado- se convierte en un elemento retórico-cultural que posibilita imaginar y delimitar hegemónicamente a la nación en oposición a sus alteridades étnicas y políticas (Jáuregui, 2008: 31) Por tanto, el sujeto indígena amazónico es desplazado del proyecto civilizatorio, es más, se constituye en un enemigo -anónimo y acechante- del avance de la civilización en el espacio amazónico, espacio que ha habitado incluso milenios antes de la constitución del Estado peruano.

La crónica de Dávalos y Lissón convierte al indígena amazónico en mera herramienta de la modernidad y niega toda capacidad de agencia de estas sociedades. Resulta por ello, interesante un artículo aparecido en la prensa limeña en marzo de $1874^{24}$. Esta noticia refleja esta acción -no aislada- de algunos pueblos indígenas amazónicos que se acercaron a los "emisarios de la civilización" pero muchas veces estos eventos no fueron registrados en las crónicas de la época y menos asumidos en los imaginarios sociales. Porque como afirma Velásquez Castro "invierten el orden "natural" de las cosas" (2017:91) Es más, en muchas ocasiones, no solo fueron estos pueblos quienes iniciaron esta búsqueda en esta "zona de contacto" (Pratt 2010) sino que viabilizaron diversas modalidades de acercamiento con otras poblaciones indígenas más alejadas. Pero Dávalos y Lissón se arropa de esta mirada colonial y concibe al indígena como salvaje, solo posible de ser doblegado por la violenta acción cauchera.

Es evidente que el cronista construye una mirada que niega las historias locales y la capacidad de agencia del sujeto indígena amazónico, desconoce la relación de siglos con Occidente -no carente de violencia- y la labor de los misioneros y otros agentes estatales que reconfiguraron esta "zona de contacto", y con aciertos y errores, establecieron una economía colonial en esa región a través de las misiones.

22

23

24

Véase Chirif y Cornejo Chaparro (Eds.), 2009.

Sobre la construcción del sujeto indígena amazónico como un ser carente de humanidad ver: Chirif, 2009.

"En un artículo titulado "La Barbarie Buscando a la Civilización" Víctor Proaño sostiene que "hay muchas tribus amazónicas que han salido en busca de cristianos y misioneros -es decir en busca de los que debían buscarlas a nombre de la civilización- [...]" (La Patria, Nº842:3; 13 de marzo de 1874). (citado en: Velásquez Castro 2017: 91) 
Dávalos y Lissón no solo omite este proceso histórico sino que legitima el accionar muchas veces violento de los caucheros:

"Lo que en algunos siglos no han conseguido las misiones evangélicas ni las comisiones científicas de todos los tiempos ${ }^{25}$, lo ha alcanzado el industrial de las gomas elásticas; á quien el espíritu de lucro ha llevado á lo más recóndito de las selvas. Para él no es un misterio lo interior de los bosques" (El Comercio, 7 de junio de 1894).

De nuevo, aparece en el relato, la figura del héroe de mímesis alta, el cauchero que es colocado no solo como agente comercial sino como emblema de la civilización ${ }^{26}$. Gracias a él ya no existen territorios desconocidos en Loreto, pero este héroe no solo es valioso por la conquista de nuevos territorios sino por la conquista de los infieles. En este término infiel se concilia la herencia colonial con las narrativas decimonónicas de la modernidad. El término infiel no solo ahistoriza y destierra al sujeto indígena amazónico del proyecto nacional finesecular sino que legitima la usurpación de su territorio y la aniquilación de sus sociedades:

"Hace diez años que lo desconocido principiaba en las mismas orillas de los ríos principales; hoy, geográficamente hablando, la palabra desconocido no existe en Mainas. El cauchero, no solamente conoce todos los ríos principales; sino, que sin excepción, ha navegado todos los afluentes de cualesquiera de ellos...pero si éstas son sus adquisiciones en Geografía, cuanto más importantes son sus conquistas con los infieles y con los territorios poblados por estos" (El Comercio, 7 de junio de 1894).

Pero aquí, habría que detenernos en esta noción de salvaje o infiel que Dávalos y Lissón presenta en la crónica. Hay que señalar que en 1914, el etnólogo alemán Konrad Preuss visitó la región del Putumayo, una zona más agreste y aislada que Loreto y señaló la dificultad de distinguir entre indígenas salvajes y civilizados ${ }^{27}$.

En una región como Loreto, con una presencia misional de varios siglos, era evidente que los sujetos indígenas amazónicos habían interactuado -la más de las

25 Dávalos omite los esfuerzos del Estado peruano en estudiar, conocer e incorporar esa región a la economía nacional. En 1888, el presidente Cáceres nombró una comisión especial para el estudio de Loreto desde diferentes perspectivas. El mismo Cáceres autorizó que 23 miembros de la Sociedad Expedicionaria de las Regiones Amazónicas recibieran apoyo para iniciar su primera exploración al Ucayali. También se pueden señalar la importancia de los viajes del Coronel Samuel Palacios (1887-1889) el de Carlos Fry (1886,1887 y 1889) (Espinoza 2016: 227-228) Así como los viajes de numerosos exploradores extranjeros.

26 Dávalos y Lissón le da un papel preponderante a la labor civilizatoria del cauchero, siguiendo con la ideología civilista. Como afirman Santos Granero y Barclay: “Las políticas civilistas respecto de Loreto no fueron sustancialmente distintas de aquellas aplicadas al resto del país. Estas políticas reflejaban una filosofía liberal que sostenía que el Estado debía intervenir lo menos posible en el ámbito de la economía, limitándose a la construcción de infraestructura básica, la recaudación de impuestos y la defensa de la soberanía nacional" (2015: 152).

27 "Por lo tanto, no es fácil distinguir entre indígenas "salvajes" e indígenas "civilizados", a no ser que aquellos sean equiparados con gente hostil, mientras que los segundos serían los que han adoptado algunos productos europeos y cambiado sus costumbres por otras foráneas" (1994: 43) 
veces de manera violenta pero otras también pacíficas- con la sociedad occidental durante siglos. Eran sujetos con saberes tradicionales y depositarios de culturas ancestrales que ya formaban parte de una embrionaria cultura regional. La cual el cronista niega , más bien ficcionaliza este episodio, creando una escena trágica, una puesta en escena, donde es inevitable la conquista -el genocidio, el exterminio, la sumisión- del sujeto indígena amazónico ${ }^{28}$. Esta representación refleja esta mirada compleja de la sociedad nacional con el espacio amazónico: un espacio donde hay ingentes recursos naturales pero también existen pueblos indígenas -de los cuales hay una estrategia de no reconocimiento- que se presentan siempre amenazantes, temibles, a los que inevitablemente hay que someter. Como sabemos, esta relación compleja de la sociedad nacional hacia la Amazonía subsiste hasta la actualidad.

"Algo providencial ha colocado á la yarina (comida del salvaje), junto á los árboles de caucho. De manera que, por lo general, es imposible penetrar a un cauchal, sin avistarse con los infieles; quienes comúnmente protestan de semejante invasión, apoyando con sus flechas dicha protesta. El cauchero, á su vez, reúne astucia y coraje para adueñarse de ese territorio que necesita, el que siempre conquista, ya sea que se resuelva á batirse con ellos ó atraérselos como amigos" (El Comercio, 7 de junio de 1894).

En los párrafos siguientes vemos que al igual que la reconfiguración de la selva tropical y agreste en un bosque bucólico y ensoñador. Lo que Humboldt denomina "bosques primordiales" y la crítica nombra terra nullis, terra incógnita se convierte en un afán por la aculturación y la inserción de los indígenas en el proyecto civilizatorio. La metamorfosis de los coloniales "indios de guerra" en republicanos "indios de paz" (Rodríguez 2000:107).

"El salvaje gusta de ser obsequiado, y mediante el regalo de escopetas, cuchillos, hachas, etc., clava en tierra su lanza que es la señal de paz y se deja dominar por el blanco, quien con engaños, le saca de la selva, le traslada á otro lugar y le convierte en semi-salvaje ó esclavo" (El Comercio, 7de junio de 1894) ${ }^{29}$.

Pero esta distinción virreinal (indios de paz y de guerra) evidencia el reconocimiento que el territorio le pertenece a alguien. Como afirma Rodríguez: “ $\mathrm{La}$ guerra es la historia no contada, o la historia que no vale la pena contar, el residuo

28 Para Dávalos y Lissón, como en la mayoría de intelectuales de la época, los pobladores indígenas nunca fueron imaginados como "agentes de progreso" su exclusión no constituye una falencia sino una estrategia de las élites, inherente al proyecto de formación del Estado-nación (Drinot 2016:30-31)

29 La mirada de Dávalos y Lissón sobre el indígena amazónico y la imperiosa labor civilizatoria del cauchero se mantiene a pesar de las sonadas denuncias (que abarrotaron la prensa limeña desde 1911) ante la irracional violencia de las empresas cauchera, en especial de la Casa Arana. En La primera centuria, publicada entre 1919-1926, como señala acertadamente Pollarolo, Dávalos y Lissón vuelve a publicar sus escritos publicados más de dos décadas antes sin ningún añadido ni corrección (2015: 138-141). 
de las etnografías, subyacente a las narrativas de exploración y colonización" (2000: 108).

"Los infieles que prefieren la guerra luchan con valor; pero á traición y siempre en retirada ${ }^{30}$. En sus derrotas pierden sus hijos, que les son robados por el cauchero, quien fácilmente encuentra comprador en ellos" (El Comercio, 7 de junio de 1894)".

Resulta relevante que a la vez que Dávalos y Lissón describe con naturalidad la violencia esgrimida por la acción cauchera, no objeta la pérdida de vidas de los indígenas ni el tráfico humano que décadas después iban a escandalizar Lima. Como precisa Weber "el Estado moderno se constituye como el monopolio del uso legítimo de la fuerza física en un territorio determinado" (citado en Ramos 1989: 38) En el caso amazónico, hay una evidente empresa comercial en llevar la civilización a los indígenas. A la hipérbole del salvaje, se le incluye el símbolo de infiel, al cual hay que civilizar por la razón o el exterminio:

"igual servicio se presta á los salvajes que el blanco saca de la selva para convertirlos en sus peones; porque si bien es cierto que estos quedan siempre salvajes, en cambio los hijos que nacen en el fundo agrícola, ya no son infieles, y cuando llegan á ser hombres, son elementos útiles para la sociedad en que viven...el loretano ha resuelto pues, civilizar al infiel, por la razón o el exterminio. O le convierte en un hombre útil ó le elimina de su paso, para poder trabajar con seguridad en los bosques" (El Comercio, 7 de junio de 1894).

En Dávalos y Lissón advertimos que no solo existe una intención de representar la Amazonía y los pueblos "salvajes" que existen allí sino además los modos posibles de intervención del Estado para llevar a cabo el proyecto civilizatorio. En este proyecto modernizador también tiene que estar presente la figura del letrado -a través de las leyes, del conocimiento- lo sugerente es que no se presentan en el relato los otros agentes de desarrollo de la época y tampoco el aparato militar $¿$ Entonces lo representado en Loreto también constituye una manera de legitimar el papel de la élite letrada en el proyecto nacional de fines del siglo XIX? ¿Los intelectuales viajeros, como Dávalos y Lissón, son aquellos destinados a tender esos puentes discursivos con la nueva clase económica dirigente?

"Hecha esta aclaración, concluiré con este resumen, diciendo que Loreto es un pueblo que se ha formado por sí, que tiene vida propia y que debe su adelanto á sus únicos esfuerzos. No se encuentra en la condición de los demás pueblos del Perú; que todo lo esperan de la acción del Gobierno. No necesita contingentes de dinero, por el contrario; muy en breve los enviará al Gobierno de Lima; solo pide para su completo desarrollo y progreso que se le den leyes sabias" (El Comercio, 5 de julio de 1894).

30 Es casi la estrategia utilizada por la resistencia de Cáceres ante los chilenos en la campaña de La Breña pero el cronista, otra vez, en lugar de asumir símiles históricos, produce discursos de alteridad. 


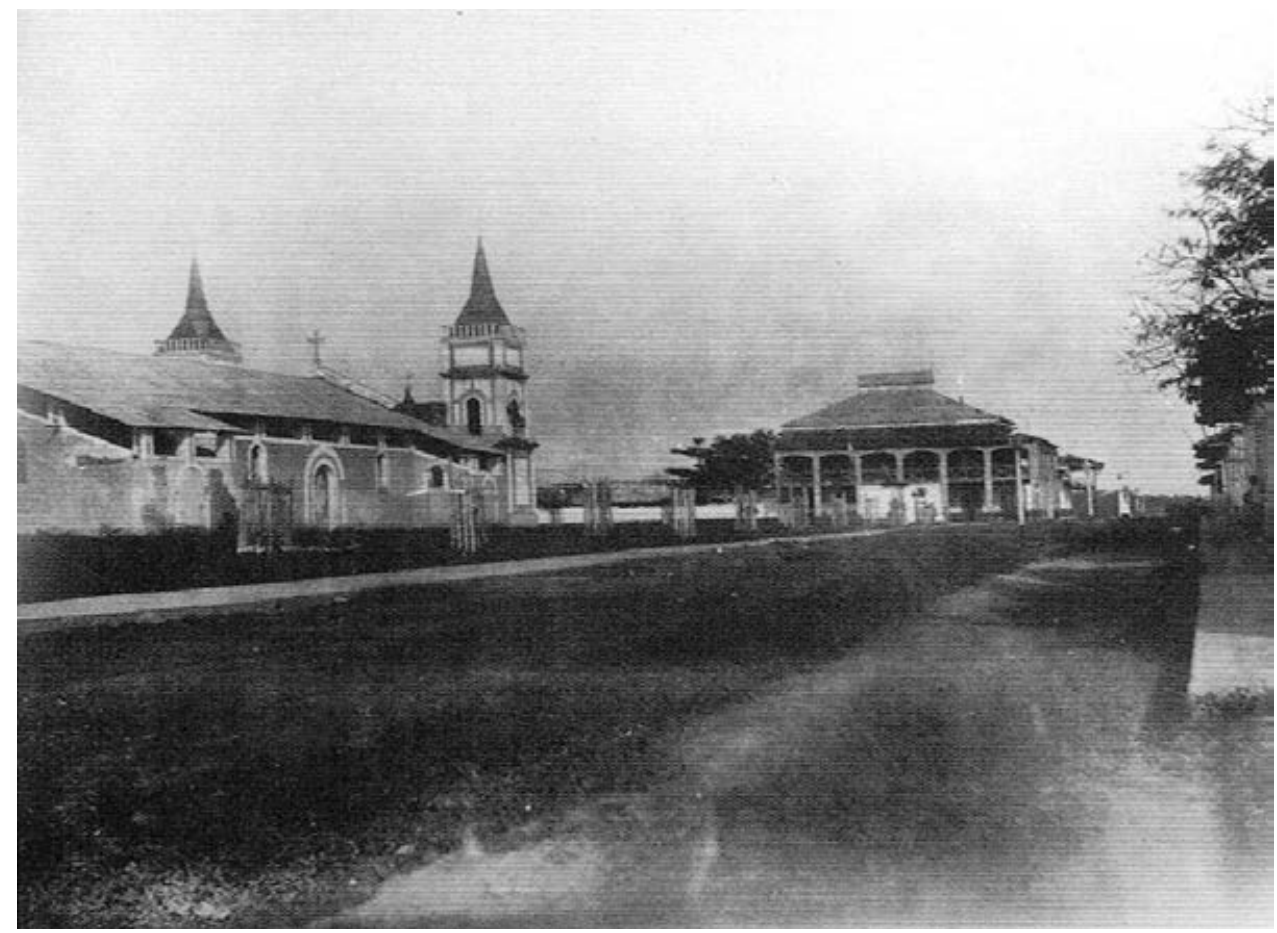

Plaza de Armas de Iquitos y Casa de fierro

Kroehle \& Huebner

ca. 1889

Archivo Jean-Pierre Chaumeil

Aquí hay que resaltar que la mirada del cronista se apropia de las voces de la clase dirigente regional y aboga por ellas ante Lima. Al manifestar que esta región "tiene vida propia y que debe su adelanto á sus únicos esfuerzos", concuerda con la noción Domesticación de la Frontera de Santos Granero y Barclay Entonces, esta región se constituye en un espacio con una economía orientada al mercado externo, con una débil articulación al resto del país y con una élite empresarial (Santos Granero y Barclay 2015) Lo que desconoce el cronista es que Loreto no aporta el ofrecido aporte al Gobierno de Lima ${ }^{31}$. Dávalos expresa la mirada de los grupos modernizadores limeños que sueñan con la integración del territorio amazónico y su incorporación al comercio mundial, merced a la obra de "emprendedores" "progresistas": empresarios privados, nacionales o extranjeros, pero también

31 “En agosto de 1894 una ley dada por el Gobierno autorizaba y urgía a las juntas departamentales y concejos provinciales a otorgarle un préstamo 'para contribuir a la pacificación'. La medida fue abiertamente resistida tanto por la Junta Departamental de Loreto como por los concejos provinciales al punto que todavía en diciembre de ese año el prefecto Rivera urgía al concejo de Bajo Amazonas haciéndole notar que las leyes no podían ser objeto de discernimiento y debían ser cumplidas" (Barclay 2009:165). 
obreros y artesanos que, escapando del marasmo y vicios con el que las elites asocia a estos grupos populares, se entreguen a la aventura de construir un país en las fronteras del territorio.

\section{“N.D. Negocios particulares"}

La crónica acaba con un postdata de Dávalos y Lissón:

“N.D. Negocios particulares me obligan á dejar en breves días más este querido suelo de Loreto; esta tierra rica y original patria de hermosas mujeres y cuna de regeneración financiera del Perú. Voy á Nueva York, por la vía de Manaos, Pará y Barbados; tres lugares poco conocidos en el Perú, sobre las cuales trataré de escribir algo para EL COMERCIO de Lima" (El Comercio, 5 de julio de 1894).

En este epílogo hay que resaltar que pese a ser un intelectual que aboga por la modernidad, defiende la labor civilizatoria y tiene una postura eminentemente liberal, el cronista utiliza el término patria para referirse al lugar de nacimiento, el espacio vital de un individuo, tal como se utilizaba en el siglo XVIII, durante la época colonial (Velásquez, 2017: 361) ${ }^{32}$. Podemos señalar las complejas corrientes discursivas, no solo entre la mirada letrada y la empresarial, sino los diversos tiempos y narrativas del cronista que complejizan su rol en la ansiada modernidad.

A esto hay que sumar, que así como en la crónica de Dávalos encontramos una traslación de la imagen de nuestra frontera interna (de la montaña a la región fluvial) también encontramos una traslación del término "regeneración de la patria", Ya no en términos simbólicos como abogaba Carlos Lissón, (tío del cronista, en 1886) ${ }^{33}$ sino en términos meramente económicos. Loreto para el cronista constituye solamente una tierra promisoria para hacer negocios, El cronista después de ocho meses de estadía en esta región enrumba a Nueva York ${ }^{34}$.

32 Aunque Velásquez afirma "que el sentido localista de patria -en alusión a unidades políticas o territoriales inferiores al Estado nacional-siguió en uso hasta la década de 1860" (2017: 375) advertimos que Dávalos y Lissón sigue utilizándolo hacia fines del siglo XIX.

33 Como señala García Jordán "fueron muchos los intelectuales... que tras la bancarrota económica, la derrota militar y la crisis política, abogaron por la regeneración del país, proyecto que, a modo de talismán, debería permitir al Perú restaurar su maltrecho orgullo nacional, sanear su economía, vertebrar su sociedad, dotarse de una nueva mentalidad y lograr la estabilidad política"(2001: 157)

34 La fecha del viaje a Nueva York concuerda con los viajes de Dávalos y Lissón por diversos países latinoamericanos que reseña Tauro del Pino (citado en Pollarolo 2015: 30) 


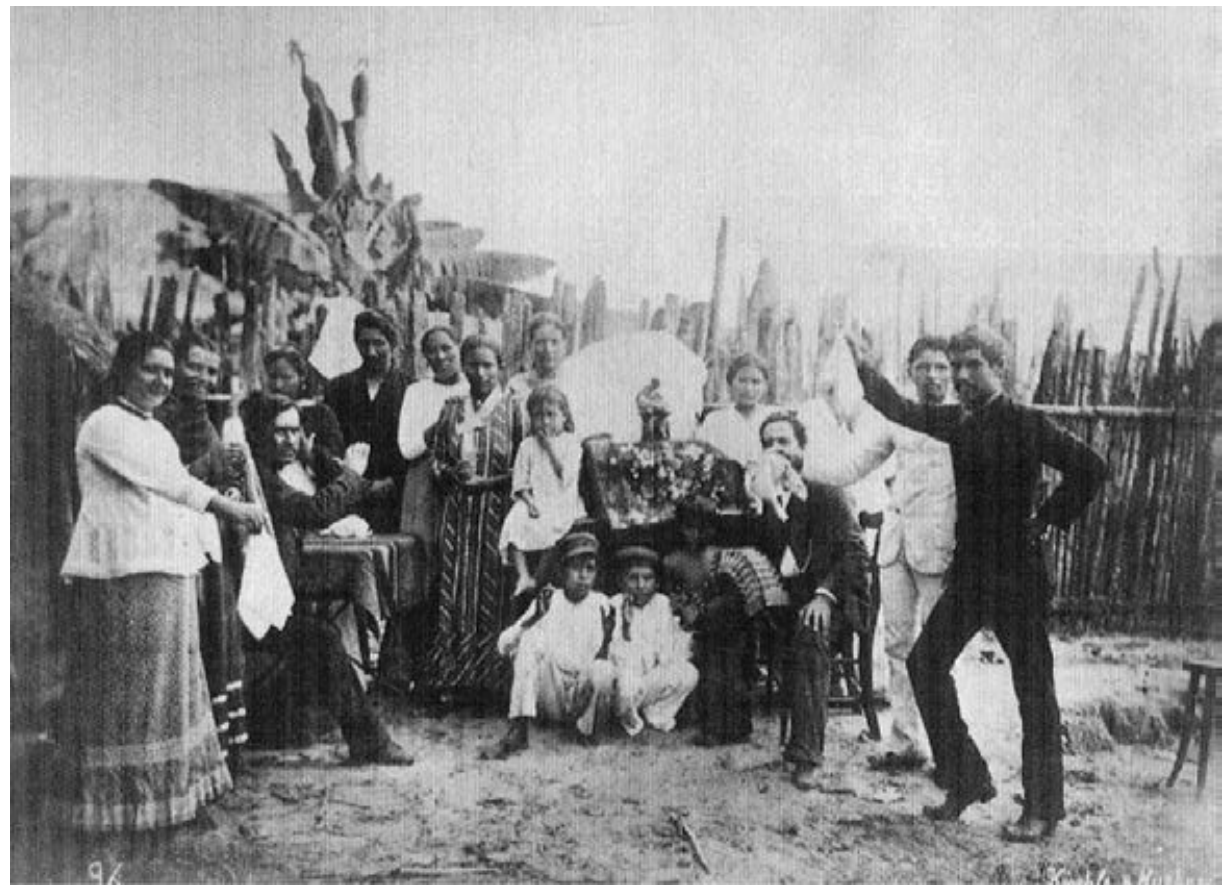

Iquiteños bailando una marinera

Kroehle \& Huebner

1888 - 1889

Archivo Jean-Pierre Chaumeil

Dávalos y Lissón como exponente del intelectual-viajero define el "buen camino" hacia la modernidad (Ramos 1989: 108) es decir, con su crónica construye una imagen de la Amazonía donde convergen la herencia colonial y el proyecto civilizatorio decimonónico. Esa Amazonía, tan lejana a la ciudad letrada, es depositaria no solo de riquezas sino provista de un capital simbólico. Constituye un no-escenario donde es imperante la presencia y ocupación nacional a través de empresas civilizatorias, como la de los pioneros caucheros y, luego, de leyes correctas por parte del Estado. Y también, y sobre todo, justifica el papel del letrado que transita -armoniosa o conflictivamente- este puente discursivo entre las letras y el novedoso mundo de la industria gomera y consolida su aporte en la construcción de ese frustrado proyecto decimonónico de nación imaginada. 


\section{BIBLIOGRAFÍA}

Barclay, Frederica

2001 "Cambios y continuidades en el pacto colonial en la Amazonía. El caso de los indios Chasutas del Huallaga Medio a finales del siglo XIX" en: Bulletin de l'Institut français d'études andines. 30 (2), pp 187-210.

Barclay, Frederica

2009 El Estado Federal de Loreto, 1896. Centralismo, descentralismo y federalismo en el Perú a fines del siglo XIX. Lima: Instituto Francés de Estudios AndinosCentro Bartolomé de las Casas.

Bendayán, Christian y Manuel Cornejo Chaparro (Eds.)

2017 En el País de las Amazonas. 150 años de fotografía. (Catálogo de la exposición) Lima: Asociación Cultural Peruano Británica.

Chirif, Alberto

2009 "Imaginario sobre el indígena en la época del caucho" en: Chirif, Alberto y Manuel Cornejo Chaparro (Eds.) Imaginario e Imágenes de la Época del Caucho: Los Sucesos del Putumayo. Lima: CAAAP-IWGIA-UCP.

Chirif, Alberto y Manuel Cornejo Chaparro (Eds.)

2009 Imaginario e Imágenes de la Época del Caucho: Los Sucesos del Putumayo. Lima: CAAAP-IWGIA-UCP.

Dávalos y Lissón, Pedro

1894 "Loreto" en: El Comercio, (11 de enero, 28 de marzo, 23 de abril, 7 de junio y 5 de julio). Lima.

Dávalos y Lissón, Pedro

1895 "Región Fluvial de Loreto" en: Boletín de la Sociedad Geográfica de Lima. Año V, Tomo V.pp. 95-108. Lima.

Drinot, Paulo

2016 La seducción de la clase obrera. Trabajadores, raza y la formación del Estado Peruano. Lima: IEP-Ministerio de Cultura.

Espinoza, Waldemar

2016 Loreto. Departamento y región (San Martín-Ucayali) 1846-2000. Lima: Universidad Nacional Mayor de San Marcos.

García Bedoya, Carlos

2012 Indagaciones heterogéneas. Estudios sonre literatura y cultura. Lima: PakarinaCELCP-UNMSM. 
García Jordán, Pilar (Ed.)

1998 Fronteras, colonización y mano de obra indígena en la Amazonía andina (siglos XIX-XX) Lima: PUCP - Universitat de Barcelona.

García Jordán, Pilar

2011 Cruz y arado, fusiles y discursos. La construcción de los orientes en el Perú y Bolivia (1820-1940). Lima: IFEA-IEP.

Jáuregui, Carlos A.

2008 Canibalia. Canibalismo, Calibanismo, Antropofagia Cultural y Consumo en América Latina. Madrid: Iberoamericana- Vervuert.

Larrabure y Correa, Carlos

2006 Colección de leyes, decretos, resoluciones y otros documentos oficiales referentes al departamento de Loreto. (18 tomos) [1905] $2^{\circ}$ edición. Iquitos: CETA-GOREL.

La Serna, Juan Carlos

2012 "Visiones del progreso, otredad y fronteras internas en la construcción de la Amazonía peruana. Una aproximación a los discursos visuales sobre la montaña a fines del siglo XIX". En: Cánepa, G. (Ed.) Imaginación visual y cultura en el Perú. Lima: PUCP. pp 221-246.

2013 "La domesticación visual de la montaña. Imágenes del territorio y población amazónica proyectadas por El Perú Ilustrado (1887-1892)". Nueva Coronica, Vol. I, N², 2013, pp. 377-394.

http://ateneo.unmsm.edu.pe/ateneo/bitstream/123456789/2549/1/ nueva_coronica10n2_2013.pdf

Palacios, Samuel

2006 "Informe que presenta al Supremo Gobierno el Presidente de la Comisión Especial al Departamento de Loreto Coronel, Prefecto y Comandante General D. Samuel Palacios sobre los estudios realizados por la expresada, de conformidad con la ley de 4 de noviembre 1887" [1890]. En: Larrabure y Correa (1905) Colección de leyes, decretos, resoluciones y otros documentos oficiales referentes al departamento de Loreto. (18 tomos) $2^{\circ}$ edición. Iquitos: CETA-GOREL.

Pizarro, Ana

2009 Amazonía: el río tiene voces. Santiago de Chile: Fondo de Cultura Económica.

Pollarolo, Giovanna

2015 De aventurero a letrado. El discurso de Pedro Dávalos y Lissón (1861-1942). Lima: Universidad del Pacífico. 
Pratt, Mary Louise

2010 Ojos Imperiales. Literatura de Viajes y Transculturación. México: Fondo de Cultura Económica.

Preuss, Konrad

1994 Religión y mitología de los uitotos. Bogotá: Universidad Nacional-Corporación Colombiana para la Amazonía-Instituto Colombiano de Antropología.

Rodríguez, Ileana

2000 "Narrativas coloniales: Exploración y exterminios. Viaje amazónico de Francisco Orellana narrado por Fray Gaspar de Carvajal”. En: Amazonía Peruana $\mathrm{n}^{\mathrm{o}} 27$.

Said, Edward

1990 Orientalismo. Madrid: Libertarias-Prodhufi.

Santos Granero, Fernando y Frederica Barclay

2015 La frontera domesticada. Historia económica y social de Loreto 1850-2000. (2002). Iquitos: Tierra Nueva Editores. $2^{\circ}$ edición.

Serje, Margarita

2005 El revés de la nación: territorios salvajes, fronteras y tierras de nadie. Bogotá: Universidad de los Andes.

Sloterdijk, Peter

2007 En el mundo interior del capital: Para una teoría filosófica de la globalización. Madrid: Siruela.

Velásquez Castro, Marcel

2017 “Civilización. 1750-1850" en: Las voces de la modernidad. Perú, 1750-1870. Lenguajes de la Independencia y la república. Cristobal Aljovín de Losada, Marcel Velásquez Castro, compiladores. Lima: Fondo Editorial del Congreso del Perú.

Velásquez Silva, David

2017 "Patria 1770-1870" en: Las voces de la modernidad. Perú, 1750-1870. Lenguajes de la Independencia y la república. Cristobal Aljovín de Losada, Marcel Velásquez Castro, compiladores. Lima: Fondo Editorial del Congreso del Perú. 
EL INDRPANDIFNTE.

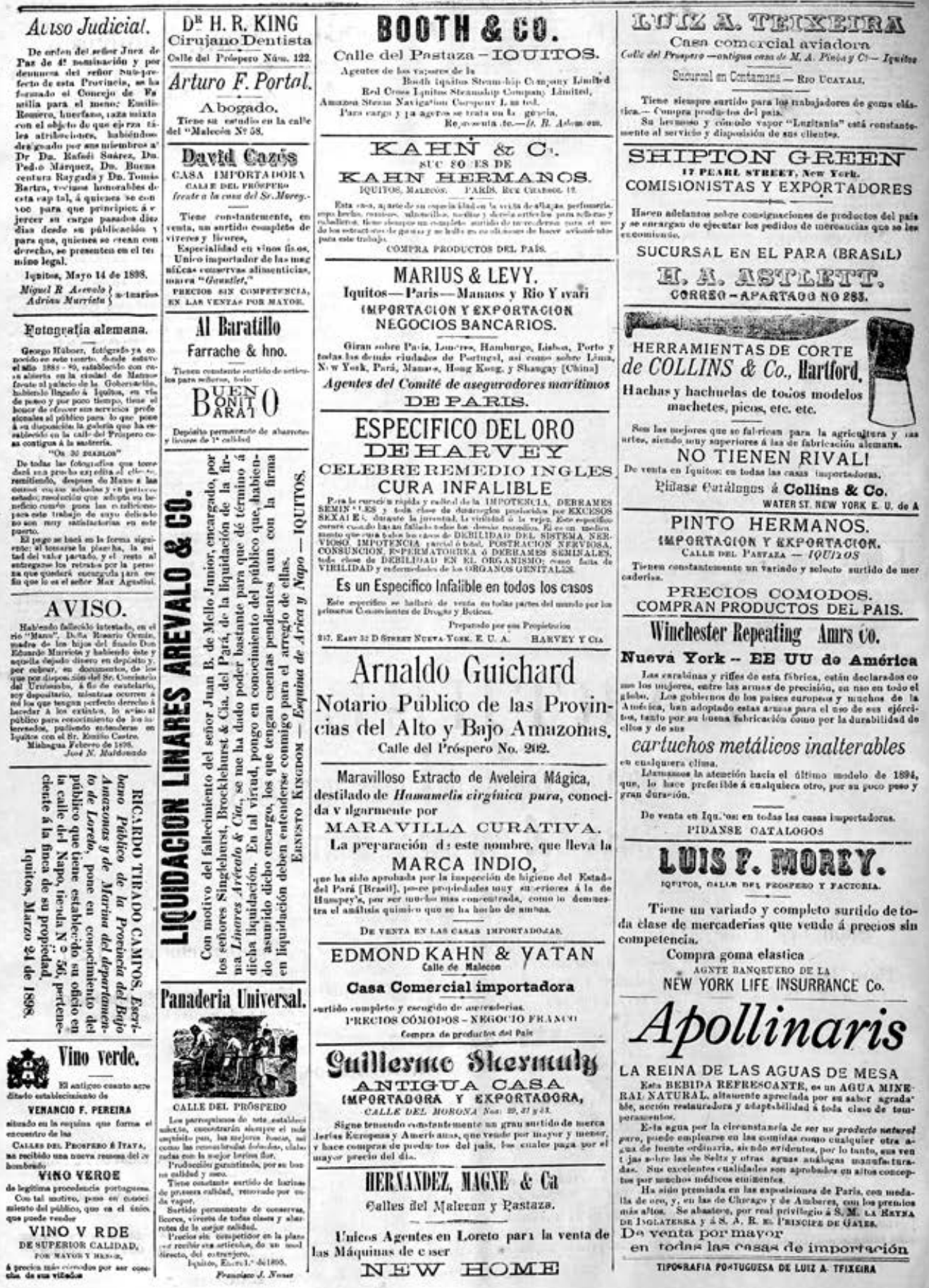

